\title{
THE NEW DUTCH LAW ON MEDICAL SERVICES
}

\author{
by Ewoud Hondius ${ }^{*}$ and Annet van Hooft ${ }^{* *}$
}

Dutch health care occasionally comes under close international scrutiny. The interest usually centres on euthanasia and assisted suicide in the Netherlands. A development of perhaps more lasting importance, however, has so far virtually escaped attention elsewhere. It is the incorporation of a bill on patients' rights into the Dutch Civil Code. This article focuses on the new Dutch Act on Medical Services, which came into force on April 1, 1995. As a point of reference, English medical law will be referred to.

\section{INTRODUCTION}

How should patients' rights be guaranteed? In the Netherlands, the legislature has opted for the solution of laying down patients' rights in the Civil Code. ${ }^{1}$ At a time when the Dutch debate on euthanasia ${ }^{2}$ and assisted suicide ${ }^{3}$ has attracted widespread attention, it seems appropriate to discuss the Medical Services Act, which is at least of the same if not greater importance for daily medical practice. Yet another reason to devote attention to the act stems from European endeavours to realise a directive on medical services. Dutch sources have expressed the hope that the Dutch act may serve as an example for the EU draftsmen.

The medical profession has in general been slow to realise the rise of a new generation of patients who do not take what the doctor says for granted. This new generation has had some of its foremost protagonists among lawyers. In the Netherlands, the aims of the patients' rights movement were first set out in 1973 by J.F. Rang in an inaugural address entitled 'Patients' Rights'. This led the

* Professor of Law, University of Utrecht.

** LLM, University of Utrecht.

1. L.F. Markenstein, 'The Codification in the Netherlands of the Principal Rights of Patients: A Critical Review', 2 Eur. J. Health L. (1995) pp. 33-44.

2. R.J.M. Dillmann and J. Legemaate, 'Euthanasia in the Netherlands: The State of Legal Debate', 1 Eur. J. Health L. (1994) pp. 81-87.

3. J. Griffith, 'Assisted Suicide in the Netherlands: The Chabot Case', (1995) 58 MLR pp. $232-248$.

Netherlands International Law Review, XLIII: 1-17, 1996

- 1996 T.M.C. Asser Instituut and Contributors RIJKSUNIVERSITEIT TE UTRECHT

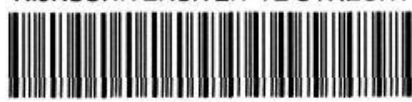


Government to ponder the question of how to implement such rights. One possibility, to leave it to the medical profession itself, was rejected. Legislation seemed more appropriate. But what kind of legislation?: should it be of an administrative nature, by requiring a licence allowing for practice only under certain conditions? Should it be left to criminal law based on the idea that any medical treatment not consented to amounts to an assault on the person? Or should what continental Europeans refer to as the civil law prevail? Once civil law had been opted for, another question arose: should the relationship between doctor and patient be based on contract or on negligence? The government has opted for a contractual approach. Most authors, although aware of some of the difficulties involved, applaud the contract option which is based on self-determination. Yet the contract model does have some disadvantages. ${ }^{4}$

First, contract presupposes a capacity to consent, a capacity that is not necessarily present in, e.g., psychiatric patients and even totally absent in comatose patients. Second, the contracting party and the patient are not always one and the same person. Children and persons subjected to examination by a medical examiner are two groups where the qualities are usually delegated to different persons. Third, a contract usually embodies rights and obligations of both parties. Instead, the medical services contract seems a very one-sided affair, with only two obligations on the side of the patient, one of which - the obligation to provide the physician with the necessary information and cooperation can hardly qualify as an obligation as such.

Yet the contract option has the major advantage that a contract is based on party autonomy. This is a natural habitat for such patients' rights as the right to information, to consent and to access to medical records. The disadvantages set out above have partly been met by the bill. Psychiatric patients and minors who cannot adequately formulate their consent are to be represented under Article 7:465. Article 7:464 declares the medical services act to be of equal applicability for those situations in which the patient is examined by a medical examiner.

\section{2.}

\section{SCOPE OF THE ACT}

The act not only applies to the activities of physicians in relation to their patients, but also applies to all contracts whereby a health care provider undertakes to provide medical treatment. The health care provider can both be a natural or a legal person, e.g., a hospital. This implies that the patient sometimes has two contracts; one with the hospital authorities for nursing and care and one with the physician for examination and treatment. This is merely different if the physician

4. See on this issue P. Allen, 'Contracts in the National Hèalth Service Internal Marker', 58 MLR (1995) pp. 321-342. 
is employed by the hospital, rather than an independent professional. The fact that the hospital is seen as a health care provider, however, does not mean that it can interfere with the fiduciary relationship between doctor and patient. Medical treatment includes treatment by dentists, midwives and so-called related nursing. The activities of pharmacists are excluded from the act.

As the reason for the introduction of the act is to protect the patient, any abrogation of the patient's rights to his/her detriment is not allowed under Article $7: 478$.

\section{FORMATION AND TERMINATION OF THE CONTRACT}

The formation of a medical services contract does not in itself raise any specific issues. Unlike the situation in the United Kingdom, Dutch health care services have never been nationalised.

Once a contractual relationship has been entered into, a physician no longer has the right to terminate this relationship. Only when he has 'important reasons' is he entitled to do so, according to Article 7:460. Having an affair with the patient and the patient moving away are two such circumstances which are mentioned in the explanatory report.

Quite a different question is whether or not a patient is entitled to specific costly treatment such as surgery. This is a budgetary question, which like the situation in other countries has led to much political controversy. Unlike the situation elsewhere, Dutch courts have occasionally ordered hospitals to provide a plaintiff with specific treatment, ${ }^{5}$ although this will usually be denied. ${ }^{6}$

4.

\section{INFORMED CONSENT}

English law, as is well known, has been reluctant to accept the American doctrine of informed consent. ${ }^{7}$ Under Dutch law, physicians are now obliged to inform the patient clearly and, if requested, in writing, about the proposed examination and treatment and about the developments concerning the examination, the

5. Court of Appeal of 's-Hertogenbosch 2 July 1990, Nederlandse Jurisprudentie 1990, 809.

6. For instance Court of Appeal of The Hague 7 March 1991, Tijdschrift voor Gezondheidsrecht $1991,394$.

7. Hills v. Potter, [1984] 1 WLR 641. See also Sidaway v. Board of Governors of Bethlem Royal Hospital and the Maudsley Hospital, [1985] AC 87, [1985] 1 All ER 643, [1985] 2 WLR 480. S.A.M. McLean, 'Litigating Disputes in Consent to Medical Treatment: The United Kingdom Position', in S.A.M. McLean, ed., Compensation for Damage/An International Perspective (1993) p. 35 , at p. 42 sees some openings in this case for a development towards informed consent. 
treatment and the condition of the patient's health. Paragraph 3 of Article 7:448 provides for a therapeutical exception.

It is remarkable that the patient not only has a right to be informed, but, under Article 7:449, has a right not to be informed as well. If the dangers of not being informed, for the patient himself or for others, outweigh the benefits, the necessary information shall, however, be provided.

Under Article 7:450 physicians need prior consent for any act emanating from a medical services contract. For patients who are not competent, the act assigns this authority to others. Minors who are not competent are represented by their parents. Though several authors have expressed their aversion to family members acting as proxies for a patient, ${ }^{8}$ Article 7:465 paragraph 3 appoints the spouse or the partner as proxy for the incompetent adult. In the absence of such persons, other family members will be appointed. This is only different if the patient has made a living will or appointed a proxy himself.

The proxy will take all decisions concerning the health care of the patient. According to Article 7:465 paragraph 4, the health care provider does not have to comply with the proxy's decisions insofar as they are incompatible with the level of care which a conscientious care provider has to provide.

\section{5.}

\section{LIVING WILLS AND PROXIES}

Under the Act on Medical Services, a living will containing a refusal of medical treatment is recognised. According to Article 7:450 paragraph 3 the refusal has to be made in writing while the person is still competent. Furthermore, the living will has to contain the clear wishes of the patient. The health care provider is allowed to deviate from the living will when he has legitimate reasons to do so.

Unlike in the United Kingdom, a patient can legally request euthanasia in his living will. The physician, however, will not be allowed to practice euthanasia if the legal requirements are not met. ${ }^{9} \mathrm{He}$ is never obliged to answer the request.

Unlike in England ${ }^{10}$ the patient also has the possibility to appoint a proxy who will take all decisions concerning the health care of the incompetent patient.

8. For the Netherlands see H.J.J. Leenen, Handboek Gezondheidsrecht, Rechten van mensen in de gezondheidszorg (1988) pp. 178-181. J.K.M. Gevers, 'De onbekwame meerderjarige patiënt', Nederlands tijdschrift voor Geneeskunde (1987) p. 2094 (contra) and E-B van Veen, 'Plaats voor een onbenoemde wettelijk vertegenwoordiger van onbekwame patiënten?', Tijdschrift voor Familie en Jeugdrecht (1993) pp. 6-10 (pro). See for the United Kingdom: P.D.G. Skegg, Law, Ethics and Medicine, Studies in Medical Law (1984) pp. 72, 73.

9. E.Ph.R. Sutorius and D.J. Jansen, 'De juridische status van het levenstestament', Ars Aequi (1991) p. 994.

10. With regard to the problematic aspects of the appointment of a proxy in health care matters under English law, see: Working Party Report, The Living Will, Consent to Treatment at the End of Life (1988) pp. 48-49. 
According to Article 7:465 paragraph 3 this appointment has to be made in writing while the person is still competent. The health care provider does not have to comply with the proxy's decisions insofar as they are incompatible with the level of care a conscientious care provider has to provide. It is generally accepted that the proxy cannot request euthanasia unless there is a clear request (for example, expressed in writing) from the patient himself. ${ }^{11}$

\section{PRIVACY}

The Dutch Act lays down several patients' rights relating to privacy. These rights apply to both physical privacy as well as to confidentiality concerning data.

Before setting out these rights, it should be observed that under Article 7:454 a physician is allowed and even required to set up a medical record, which he shall preserve for at least ten years. Under Article 7:455 the physician must destroy the record at the patient's request, unless keeping the record is in the interest of another patient or required by statute. Unlike English law, the Dutch act's Article 7:456 allows patients unlimited access to all medical records, unless another person's right to privacy might thereby be infringed. For providing copies, the doctor may claim reasonable costs.

The right to physical privacy implies that the physician carries out his activities outside the perception of others, although other persons whose professional assistance is required are allowed to be present. Confidentiality concerning data implies that the physician will not supply data to persons other than the patient without his consent. Other professionals directly concerned with the treatment of the patient may receive the necessary data as well.

The supply of data, however, may take place without the patient's consent if these data are required by law, e.g., in the case of certain contagious diseases. Provision without consent may also take place for statistic or scientific research. Article 7:458 paragraph 1, however, then requires that in such a case it must be impossible to ask the patient for his consent. The health care provider has to ensure that the data will not be convertible to the patient.

\section{LIABILITY}

Yet another major difference between Dutch and English law concerns the medical malpractice test to be applied. Under Article 7:453, the physician shall apply the care of a conscientious physician and shall act in accordance with the

11. H.J.J. Leenen, 'Incompetente meerderjarigen, vertegenwoordiging van de patiënt', Tijdschrift voor Gezondheidsrecht (1988) p. 229. J.K.M. Gevers, 'De onbekwame meerderjarige patiënt', Nederlands Tijdschrift voor Geneeskunde (1987) p. 2095. 
responsibility emanating from the accepted professional standard. Before this test was enacted, it had already been accepted by the Dutch Supreme Court, the Hoge Raad, in Speeckaert v. Gradener. ${ }^{12}$ Before 1991, there had been a prolonged controversial argument in legal writing, not unlike the English post-Bolam polemic, ${ }^{13}$ as to the test to be applied.

The provision does not seem to give physicians and courts much guidance as to what is a conscientious physician. One of the more specific provisions lays down that in principle the physician whom the patient has contracted with shall also perform the treatment. Here the model contract, which has been drafted in advance of legislation by the Koninklijke Nederlandse Maatschappij voor Geneeskunst (to be compared with the British Medical Association) in cooperation with the Landelijke Patiënten/Consumenten Platform, a large patients' organisation, may provide some useful additions. ${ }^{14}$ Thus under Article 11 , the physician shall use fitting materials and means; according to Article 12, one physician shall be appointed as the contact person, in case more physicians are concerned with the treatment. Under Article 32 the physician shall appoint a capable and competent locum. Article 36 entitles the patient to a second opinion and, on a different level, Article 38 provides that the physician shall specify his bill.

With Dutch physicians exercising their profession either as independent professionals or as hospital employees, it has always been a major difficulty for patients to discover whom they have contracted with. This difficulty becomes especially apparent when a nurse has acted negligently. Who is the nurse's employer? Article 7:462 tries to solve this problem by making the hospital jointly liable in the event of any deficiency for any treatment carried out in the hospital. Under Article 7:463 a health care provider's or a hospital's liability may not be exempted or limited.

The new act does not lay down any rules as regards the burden of proof. The Hoge Raad, however, has developed a line which comes close to a reversal of the burden of proof: the health care provider shall provide the patient with the documents which will enable him to prove the care provider's fault. ${ }^{15}$ This

12. Hoge Raad 9 November 1990, Nederlandse Jurisprudentie 1991, 26.

13. Bolam v. Friern Hospital Management Committee [1957] 1 WLR 582 determined that a surgeon must exercise such care as accords with the standards of reasonably competent medical men at the time. This was further developed and extended in Stokes v. Guest, Keen and Nettlefold (Bolts and Nuts) Ltd., [1968] 1 WLR 1776 in that if the surgeon has greater than average knowledge of any risks, he may be obliged to take more than average precautions.

14. As to the legal nature of the model contract see C.J.J.M. Stolker, 'De nieuwe Wet geneeskundige behandelingsovereenkomst en het juridisch belang van de Modelregeling arts-patiënt', Nederlands Tijdschrift voor Burgerlijk Recht (1994) pp. 115-119.

15. Timmer v. Deutman, Hoge Raad 20 November 1987, Nederlandse Jurisprudentie 1988, 500 . 
reversal of the burden of proof is even applied where the patient denies that the care provider has given him sufficient information. ${ }^{16}$

\section{REMEDIES}

In case the patient is not content with the services supplied under the contract, several remedies are available. It is a remarkable fact that none of these remedies have been laid down in the Medical Services Act itself. First of all the patient can address his complaints to a grievance committee, e.g., of patients' organisations, organisations representing the professions concerned or of the hospital itself. Furthermore, the patient can always file a complaint to the disciplinary council. In case of severe mishaps the Public Prosecutor may decide to commence criminal proceedings.

However, if the patient wants compensation, he will have to commence civil proceedings on the ground that a breach of contract has taken place. In case the health care provider is employed by a hospital or medical legal person, the employer will be indicted.

As a rule the burden of proof is laid squarely on the patient, though the health care provider has to supply sufficient information to create a possibility for the patient to succeed in providing this proof. ${ }^{17}$ Certain circumstances, however, can justify a reversal of the burden of proof. ${ }^{18}$

9. FUTURE DEVELOPMENTS

In the preceding paragraphs, some developments in medical law have not yet been touched upon. They are the development of arbitration schemes, the advantages and disadvantages of a patient insurance system and the fear of 'American situations'.

As in England, the question whether or not arbitration should be introduced in medical matters has arisen in the Netherlands. ${ }^{19}$ But whereas in England the discussion seems to have been prompted by the hight cost of ordinary litigation, in the Netherlands, on the other hand, the absence of patient redress has been at the root of the movement. This 'access to justice' argument has led the Dutch Government to actively sponsor and subsidise a scheme of consumer arbitration tribunals, of which there are now some 20 , most of them operating under the

16. Schepers v. De Bruijn, Hoge Raad 18 February 1994, Rechtspraak van de Week 1994, 60.

17. Timmer v. Deutman, Hoge Raad, 20 November 1987, n. 15 supra.

18. Schepers v. De Bruijn, Hoge Raad, 18 February 1994, n. 16 supra.

19. W.R. Kastelein, Van klagen naar klachtrecht/Het klachtrecht van de patiënt in de gezondheidszorg (1992). 
umbrella of a bi-partisan consumer-industry organisation. The idea has been developed to incorporate an arbitration tribunal for medical complaints in the existing consumer complaints board scheme. In fact, the Koninklijke Nederlandse Maatschappij voor de Geneeskunst was prepared to go along with this but at the last moment the idea was unfortunately rejected by the Netherlands' major insurance company and by a major patients' organisation.

In the Netherlands, like in England, ${ }^{20}$ the Swedish Patients Insurance Scheme has attracted much attention, ${ }^{21}$ but an attempt by one insurance company even to study the possibility of its implementation in the Netherlands was met by such hostile reaction from some of the hospitals that it had to be abandoned. At present, there is no likelihood that a no-fault accident scheme will be introduced.

Finally, the rapidly rising numbers of malpractice claims and the ensuing increase in insurance premiums have led many doctors - and some lawyers to fear that we are beginning to lean towards 'American situations'. In 1989, a Dutch law lecturer went to the US to discover whether things were really as bad as the media suggested. His answer was that they were not as bad; they were worse $!^{22}$ Although, as in England, the situation in the Netherlands is quite different from that in the United States, there are, however, some ominous signs, e.g., in 1994 one of the large Dutch insurance companies discontinued its medical liability insurance.

10.

\section{CONCLUSION}

Dutch and English medical law are very far apart. On some major issues, like the organisation of health care, the representation of those incompetent by family members, living wills, powers of attorneys, remedies and the burden proof, they provide different solutions. The sources are different as well. Whereas in the Netherlands statute law (law that departs from a general rule) is used, in the United Kingdom it is still left to the courts to find a solution for any specific case. This often leads to very elaborate reasoning, in which all relevant arguments are extensively treated. In the Netherlands, the application of a single rule does not require so elaborate reasoning. Yet it is very interesting to learn from each other.

20. See M. Brazier, 'The Case for a NO-Fault Compensation Scheme for Medical Accidents', in S.A.M. McLean, ed., Compensation for Damage/An International Perspective (1993) pp. 51-74 (pro) and S.A.M. McLean, 'Can No-Fault Analysis Ease the Problems of Medical Injury Litigation?', in the same volume, pp. 75-90, as well as M.A. Jones, Medical Negligence (1991) pp. 6-9 (contra).

21. B.A.J.M. de Mol, Medisch letsel in het ziekenhuis no-faultverzekering/Een verkennende studie (1988).

22. C.J.J.M.Stolker, Vanartsnaaradvocaat/Aansprakelijkheidvoormedische fouten in Ameri$k a$, Een les voor Nederland? (1989). 


\section{APPENDIX: DUTCH MEDICAL SERVICES ACT 1994}

Act of 17 November 1994 (Staatsblad 837) to amend the Civil Code and other legislation in connection with the incorporation of provisions concerning the contract to provide medical services, as renumbered by the Decree of the Minister of Justice of 15 December 1994 (Staatsblad 837).

\section{BOOK 7, TITLE 7, SUBCHAPTER 5 CIVIL CODE}

The contract for medical services

\section{Article 7:446: Scope of application}

1. The contract concerning medical services - in this subchapter hereinafter referred to as the contract for medical services - is the contract whereby a natural person or a legal person, the health care provider, in pursuance of his professional or business activities in respect of another party, the principal, undertakes to provide medical services directly relating to the person of the principal or of a specific third party. The party to whose person the medical services directly relate shall hereinafter be referred to as the patient.

2. The provision of medical services shall be understood to mean:

a. all activities - including examination and giving advice - which directly concern a person and which are intended to cure that person of a disease, to prevent that person from contracting a disease or to assess the condition of that person's health, or which constitute obstetrical assistance;

b. activities other than those referred to under a. which directly concern a person and which are carried out by a physician or dentist in a professional capacity.

3. The activities, referred to in paragraph one, shall include nursing and care of the patient related thereto as well as the direct provision for the patient of the material framework within which such activities may be carried out.

4. Activities as referred to in paragraph one shall not include activities relating to the preparation of medicines within the meaning of the Act on the Supply of Pharmaceutical Products, where such activities are carried out by a registered chemist within the meaning of the said act. 
5. There shall be no contract for medical services if the activities are carried out to assess the condition of a person's health or to provide medical care to a person under the authority of another person with regard to the settlement of claims or duties, the acceptance by an insurance or care facility, or the assessment of one's aptitude for an education, a labour relation or the exercise of certain work.

\section{Article 7:447: Minors}

1. A minor who has reached the age of sixteen years shall be competent to conclude a contract for medical services for himself, and to carry out legal acts directly connected with the contract.

2. The minor shall be liable for the fulfilment of any obligations resulting from the contract, without prejudice to his parents' obligation to bear the costs of care and upbringing.

\section{Article 7:448: Informed consent}

1. The health care provider shall inform the patient clearly and, if requested, in writing, about the proposed examination and treatment and about the developments concerning the examination, the treatment and the condition of the patient's health. The health care provider shall inform a patient who has not yet reached the age of twelve years in such a way as fits his comprehension.

2. In the pursuance of the obligations under paragraph one the health care provider shall be guided by that which the patient reasonably needs to know about:

a. the nature and the purpose of the examination or treatment which he considers necessary and of the activities which are to be carried out;

b. the likely consequences for and risks to the patient's health;

c. other possible types of examination or treatment;

d. the prospects for the latter's health from the point of view of the field to which the examination or treatment relates.

3. The health care provider shall only be entitled to withhold information as referred to above where the provision of such would clearly be to the serious disadvantage of the patient. If the patient's interests so require, the health care provider should impart the said information to a party other than the patient. Such information shall still be communicated to the patient as soon as there is no further danger of the said disadvantage arising. The health care 
provider shall not use the competence referred to in the first sentence other than after consulting another health care provider about the matter.

\section{Article 7:449: Right not to know}

If the patient has stated that he does not wish to receive any information, it shall not be provided, except where the patient's interests in not receiving information are outweighed by the detrimental effects which failure to provide information might have on him or others.

\section{Article 7:450: Consent}

1. The patient's consent shall always be required for activities in pursuance of a contract for medical services.

2. If the patient is a minor who is at least twelve years of age, but who is not yet sixteen years of age, the consent of the parents who exercise the parental control over him, or his guardian shall also be required. An activity may, however, be carried out without the consent of the parents or the guardian if it is clearly necessary in order to prevent serious harm to the patient, and if the patient, even after consent has been refused, adheres to a well-considered desire that the activity be carried out.

3. In case a patient over sixteen years of age cannot be considered capable of a reasonable valuation of his interests concerned, the health care provider and the person referred to in paragraphs two or three of article 7:465, shall follow the patient's clear views laid down in writing when he was still capable of such reasonable valuation and containing a refusal of consent as referred to in paragraph one. The health care provider may depart herefrom when he considers legitimate reasons therefor are present.

Article 7:451: Record of consent

At the patient's request the health care provider shall in every case record in writing those activities of a major nature for which consent has been given.

Article 7:452: Cooperation by the patient

The patient shall to the best of his ability provide the health care provider with the information and cooperation reasonably required by the latter for the performance of the contract. 
Article 7:453: Level of care

In the exercise of his activities a health care provider shall exercise the level of care expected from a conscientious health care provider and he shall act in accordance with the responsibility following from the professional standard for health care providers.

\section{Article 7:454: Records}

1. The health care provider shall open a file on the patient's treatment. In this file he shall keep notes of data concerning the patient's health and the activities carried out in relation to the patient and he shall place therein such other documents containing such data as are necessary for a conscientious provision of health care for the patient.

2. If requested, the health care provider shall add a declaration by the patient concerning the documents contained in the file.

3. Without prejudice to the provisions of article $7: 455$, the health care provider shall keep the documents referred to in the previous paragraphs for a period of ten years, effective from the date on which they were drawn up, or as much longer as may reasonably be expected from a conscientious health care provider.

\section{Article 7:455: Destruction of records}

1. The health care provider shall destroy the documents referred to in article 7:454 which are kept by him, within three months after the patient has made a request to that effect.

2. Paragraph one shall not apply insofar as the request relates to documents which, if kept, may reasonably be thought to be of considerable importance to a party other than the patient, as well as insofar as the destruction of documents is prohibited by virtue of or pursuant to statutory provisions.

\section{Article 7:456: Access to records}

If requested the health care provider shall provide the patient as soon as possible with access to and copies of the documents referred to in article 7:454. The provision will not take place insofar as this is necessary for the protection of another party's privacy. The health care provider may charge a reasonable fee for the provision of copies. 


\section{Article 7:457: Provision of information}

1. Without prejudice to the provisions of the second sentence of article $7: 448$ paragraph three, the health care provider shall not provide persons other than the patient with information about the patient or give them access to or copies of the documents referred to in article 7:454 without the patient's consent. If provision takes place, this will only occur insofar as it does not harm another party's privacy. The provision may occur without the restrictions referred to in the previous sentences if this is compulsory by virtue of or pursuant to statutory provisions.

2. Persons other than the patient shall not include those who are directly involved in the performance of the contract for medical services and the person who is acting as a substitute for the health care provider, insofar as provision is necessary for the activities in that regard.

3. Nor shall this category include persons whose consent is required in connection with the performance of the contract for medical services pursuant to articles 7:450 and 7:465. However, if the health care provider by supplying information concerning the patient or by giving access to or copies of the patient's documents cannot be considered to comply with the level of care expected from a conscientious health care provider, he shall not take such a course of action.

\section{Article 7:458: Scientific research}

1. Contrary to the provisions of article 7:457 paragraph one, information about the patient or access to documents referred to in article 7:454 may, without the consent of the patient, be provided to another party if this information is needed for the purpose of statistical or other scientific research relating to public health, if:

a. it is in all reasonableness impossible to ask for consent and concerning the performance of the research such guarantees are provided that the privacy of the patient will not be disproportionally harmed, or;

b. it is in all reasonableness impossible to ask for consent regarding the nature and purpose of the research, and the health care provider has taken care that the data shall be provided in such a way that conversion to individual natural persons reasonably shall be prevented.

2. Provision according to paragraph one shall only be possible if the following conditions have been met:

a. the research serves the public interest;

b. the research cannot be carried out without the relevant data; and 
c. insofar as the patient concerned has not expressly objected against such a provision.

3. In case of a provision in accordance with paragraph one, a note of this shall be kept in the file.

\section{Article 7:459: Observers}

1. The health care provider shall perform the activities relating to the contract for medical services without being observed by persons other than the patient, unless the patient has consented to the presence of outside observers during the said activities.

2. Persons other than the patient shall not include persons whose professional assistance is required in the performance of an activity.

3. Nor shall this category include those whose consent is required concerning activities carried out pursuant to articles 7:450 and 7:465. However, if allowing observers to be present may not be considered compatible with the level of care expected from a conscientious health care provider, the latter shall not take such a course of action.

\section{Article 7:460: Right to terminate}

Unless there are important reasons for doing so, a health care provider may not terminate the contract for medical services.

Article 7:461: Fees

The principal owes the health care provider payment, except insofar as the latter receives payment for his work by virtue of or pursuant to statutory provisions or on some other basis as provided for in the contract.

\section{Article 7:462: Hospital liability}

1. If activities in pursuance of the contract for medical services are carried out in a hospital which is not a party to the contract, the hospital shall be jointly liable in the event of any deficiency, as if it were itself a party to the contract.

2. The term 'hospital' as referred to in the paragraph 1 shall be understood to mean any institution or part of an institution recognised under the Health Insurance Act or the Exceptional Medical Expenses (Compensation) Act as 
a hospital, nursing home or mental institution, as well as teaching hospitals, abortion clinics within the meaning of the Termination of Pregnancy Act and dental clinics within the meaning of the Dental Clinics Act of 1986.

\section{Article 7:463: Exemption clause}

The liability of the health care provider or, in the case referred to in article $7: 462$, of the hospital, cannot be limited or excluded.

\section{Article 7:464: ${ }^{23}$ Equal applicability}

1. If in the pursuance of a medical profession or business medical services are provided, otherwise than according to a contract for medical services, this subchapter as well as articles 7:404, 7:405 paragraph two and 7:406 of subchapter one of this title shall be of equal applicability, insofar as the nature of the legal relationship is not incompatible with the application.

2. If activities as referred to in article 7:446 paragraph five are concerned:

a. the documents referred to in article 7:454 shall only be kept as long as it is necessecary for the purpose of research, unless provisions by virtue of or pursuant to statutory law prohibit destruction.

b. the person whom the examination concerns shall be given the opportunity to announce if he wants to be informed about the results and the consequences of the examination and, if desired, if he first wants to take note in order to be able to decide if others shall be informed thereof.

\section{Article 7:465: Legal representatives}

1. Any obligations resulting from this subchapter on the part of the health care provider shall, in case the patient has not yet reached the age of twelve years, be fulfilled by the health care provider towards the parents exercising parental control over the patient or towards the patient's guardian.

2. The same shall apply if a patient has reached the age of twelve years, but cannot be considered capable of a reasonable valuation of his interests concerned, unless the patient in question has reached the age of majority and is under guardianship or if for the benefit of the patient a mentor ${ }^{24}$ has

23. Art. 7:464 of the Civil Code shall enter into force with effect from the first calendar month after a period of five years following the date referred to in paragraph one.

24. The mentor is a natural person, appointed by a judge, who represents the person who has reached the age of majority but cannot be considered capable to valuate his non-material interests because of a mental of physical deficiency. 
been appointed, in which cases obligations shall be fulfilled towards the guardian or mentor.

3. If an adult patient cannot be considered capable of a reasonable valuation of his interests concerned and he has not been placed under guardianship and neither has a mentor been appointed for his benefit, any obligations towards the patient arising on the part of the health care provider from this section shall be fulfilled towards the person authorised in writing by the patient to act on his behalf. In the absence of such a person, or in the event of such a person failing to take the necessary steps, obligations shall be fulfilled towards the patient's spouse or partner, unless that person refuses, or, in the absence of the latter, towards a parent or child of the patient, unless that person refuses.

4. The health care provider shall fulfil his obligations towards the legal representatives of the patient as referred to in paragraphs one and two and the persons referred to in paragraph three, unless the fulfilment is not compatible with the level of care expected from a conscientious health care provider.

5. The person towards whom the health care provider under paragraph two or three is obliged to fulfil the obligations that result from this subchapter shall act in accordance with the level of care expected from a conscientious representative. This person is obliged to involve the patient as much as is possible in the fulfilment of his task.

6. If the patient resists an activity of a major nature for which a person as referred to in paragraph two or three has consented, the activity will only be carried out if this is clearly necessary to avoid serious harm for the patient.

\section{Article 7:466: Emergencies}

1. If the consent required pursuant to article 7:465 for the performance of an activity need only be obtained from a person within the meaning of that article instead of from the patient, the activity may be carried out without such consent if there is insufficient time to obtain such consent on the grounds that immediate performance of the activity is clearly necessary in order to prevent serious harm to the patient.

2. Consent as required by articles 7:450 and 7:465 may be considered to have been given if the activity in question is not of a major nature. 
Article 7:467: Human tissue

1. Anonymous human tissue and organs separated from the body may be used for medical statistical or other medical research insofar as the patient from whom the tissue or organ originates does not object to such research and the research is conducted with due care.

2. Research with anonymous human tissue and organs separated from the body is research whereby it is guaranteed that the human tissue to be used in the research and the data based thereupon are not convertible to a person.

Article 7:468: Mandatory law

Parties may not derogate to the detriment of the patient from the provisions of this subchapter nor from articles 7:404, 7:405 paragraph two and 7:406 of subchapter one of this title. 
